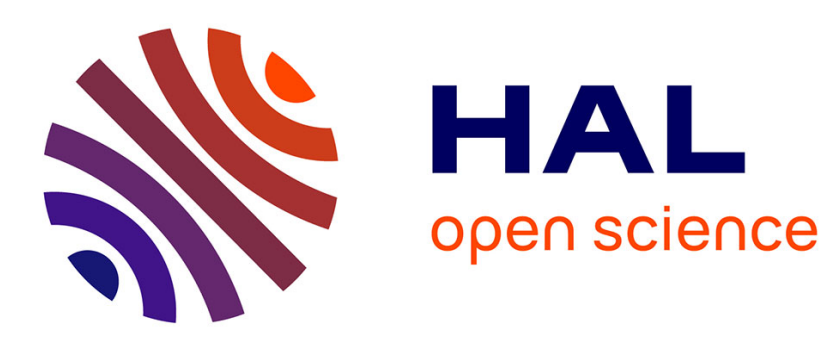

\title{
Fertility Trends, Marriage Patterns and Savant Typologies in Albanian Context
}

Albert Doja

\section{To cite this version:}

Albert Doja. Fertility Trends, Marriage Patterns and Savant Typologies in Albanian Context. Journal of Family History, 2010, 35 (4), pp.346-367. 10.1177/0363199010381045 halshs-00516607

\section{HAL Id: halshs-00516607 https://shs.hal.science/halshs-00516607}

Submitted on 10 Sep 2010

HAL is a multi-disciplinary open access archive for the deposit and dissemination of scientific research documents, whether they are published or not. The documents may come from teaching and research institutions in France or abroad, or from public or private research centers.
L'archive ouverte pluridisciplinaire HAL, est destinée au dépôt et à la diffusion de documents scientifiques de niveau recherche, publiés ou non, émanant des établissements d'enseignement et de recherche français ou étrangers, des laboratoires publics ou privés. 


\title{
Fertility Trends, Marriage Patterns, and Savant Typologies in Albanian \\ Context
}

\author{
Albert Doja'
}

\begin{abstract}
In this article, the author focuses on the speculative literalism and typologism in current scholarship to construct a taken-for-granted view, taking issue especially with many points raised in the literature on the subject that have associated fertility rates in Albania more closely with the existence of patriarchal cultural traits. This leads the author to argue that the specific rationale for the myth of many children, high fertility rates, and complex family structures in Albanian context, as elsewhere in patrilineal societies, is an ideological elaboration of patriarchy. Methodologically, the analysis of the standard view of childbearing, based on standard ethnographic methods, traditional historical sources and aggregate demographic data, is aimed to illustrate the inadequacy of the historical-ethnographic paradigm against the available empirical evidence. In turn, understanding how ideological elements are emphasized in cultural activism should lead, against current scholarship claims, to an understanding of the way in which the urgent need for male children must have been to hide away other more troubling reasons.
\end{abstract}

\section{Keywords}

culture, activism, patriarchy, ideology, childbearing, Albanian

\section{Introduction}

A significant fraction of scholarly and popular scrutiny has focused on Albanian society and culture, treating patriarchal values and practices in relation to fertility rates and population growth as a social and political problem in need of rapid attention. By contrast, the perspective I adopt here is aimed to demonstrate that reproductive rates in Albanian context as elsewhere are social products, resulting into a variety of forms of cultural practice, deeply embedded in local politics. There are many reasons to argue that patriarchal values as they are exemplified in discourses and practices would have some bearing on a wide range of reproductively relevant actions, from sexual practice to marriage to childbearing to infant mortality, such that a narrow focus on fertility rates will be misleading. Patriarchy as ideology plays an important role in making social worlds and local politics, but my

\footnotetext{
'University College, London, UK, and European University,Tirana, Albania
} 
argument does not only imply that fertility and patriarchal practices are densely interrelated in personal or collective experience in a specific time and place. Rather, the point is that the structure and consequences of this dense interrelation are more important than it appears and that we must question the simple generalizations asserted by scholarly and faux-scholarly popular press. This means that culturally grounded interpretations of the relationship between patriarchy and reproduction are not only interesting to anthropological analysis but also absolutely necessary.

The centrality of reproduction is shown to consist not only as the means by which both individuals and collectivities assure their continuity but also for theorizing social dynamics. ${ }^{1}$ Human reproduction is a ground for political battles in part because individuals, families, communities, and other social actors all understand themselves as having much at stake in the control of childbearing and child rearing. Historically constructed and variable, these multiple perspectives and interests in reproduction are often at odds. Social historians, anthropologists, and historical demographers have conceptualized a millennium of changing population pyramids in Europe as the result of diverse and variable family strategies. This is because families understand themselves to have important stakes in reproduction, whether to ensure the inheritance of land, name, and property, to cement social continuity, to provide objects of love and recipients for consumption, or to fill family needs for labor or income. However, scholars have also shown that within families there are often systematic struggles between men and women, as well as between generations, about arrangements for the timing, gender, and number of their offspring.

Definitely moving beyond well-worn functionalist arguments about the "need" for human reproduction in sustaining social systems or in providing labor power, within the course of the argument and critical analysis adopted here, I will rather assume that a special attention is paid to the diverse discourses that shape beliefs and everyday practices of reproduction, to examine their contingency and conflict and the often unintended effects on the historical construction, authorization, and justification of political action and actors. When viewed within this light, they form part of what Michel Foucault has called "biopolitics." If this is the case and we recognize reproduction as a locus for social control, a fundamental question must be asked in relation to the mechanisms used by a social system to justify such political action, in this case how the patrilineal kinship system elaborates patriarchal ideology.

After a presentation of main data and methods and a rapid critical assessment of accounts already produced in the literature, the analysis of the standard view of childbearing is expected to clarify some peculiarities of the Albanian context and illustrate the inadequacy of the historicalethnographic paradigm against the available empirical evidence. I focus particularly on the speculative literalism and typologism in current scholarship to construct a taken-for-granted view, taking issue especially with many points raised in the literature on the subject that have associated fertility rates in Albania more closely with the existence of patriarchal cultural traits. This leads me to consider the specific rationale for the ideological elaboration of patriarchy. While the agnatic kinship system was significant to the conception of women as responsible for the reproduction of the next generation of males to carry on the lineage, which as elsewhere in patrilineal societies was also the rationale behind patriarchal practices of women's subordination to male authority, understanding how these ideological elements are emphasized in cultural activism should lead, against current scholarship claims, to an understanding of the way in which the urgent need for male children must have been to hide away other more troubling reasons. Specifically, the process by which the tracks of community power become evident must be uncovered in political and disciplinary discourses as well as in widespread cultural practices that altogether attempt to assert authority over the control of women's fertility.

\section{Data and Method}

Methodologically, the analysis presented in this article is based on traditional historical sources, demographic data, and ethnographic methods. Building fertility histories and trends in Albania for 
the period before World War II is considered difficult by statisticians and demographers or policy-oriented specialists. Even though available data on crude birth rates may have started on an institutional basis only after 1945 , at a time when the vital statistics registration system was set up in Albania, significant data on vital statistics may be drawn from different religious vital registers and Ottoman tax registers starting from as far back as the early fifteenth century and going increasing afterward. ${ }^{3}$ These and other historical sources now provide modern historians with a relatively accurate picture of the size of families and their demographic and religious structure in both rural and urban areas. Another instrument the quality of which has been underestimated in the scholarly literature until recently is the "Census of the districts of Albania occupied by Austro-Hungarian troops in 1916-1918," organized under the supervision of a Graz-based expert in demographic statistics. ${ }^{4}$ The surviving material covering the major part of Albania is kept in the Archives of the Austrian Academy of Sciences in Vienna. ${ }^{5}$

The first population censuses conducted by the Albanian governmental administration were taken in 1923, 1930, and 1938, followed by the census taken by Italian administration in 1942. Even though many of the results on a macro level have been published or the original data are still available, the quality of such data is questionable for a variety of reasons. Most important of all was the high level of illiteracy in the country, which affected the registration of all events. In addition, one needs to take into account that the vital statistics registration system had just been introduced and was either incomplete or nonexistent in some of the less developed areas of the country. Consequently, there was either a lack of data for complete regions or inaccurate reporting of the vital events for that period. The general scholarly opinion is that in Albania accurate population censuses were carried out only after the census of 1945 , succeeded by the censuses of 1950, 1955, 1960, 1969, 1979, 1989, and 2001, the results of which have been published by the Albania Statistical Office since the early $1990 \mathrm{~s} .^{6}$

Since 1992, the World Health Organization (WHO), United Nations Children's Fund (UNICEF), United Nations Fund for Population Activities (UNFPA), United States Agency for International Development (USAID), and other major international organizations in collaboration with the National Institute of Statistics and the Institute of Public Health have produced numerous reports based on rapid surveys documenting maternal and child health in Albania. In the 2000s, individual data become available from a number of multipurpose household surveys, drawing heavily on the information from the Population and Housing Census conducted in April 2001. These include data from the Reproductive Health Survey conducted in $2002,{ }^{7}$ the qualitative research study of the Family Planning Project conducted from 2004 to 2007 using ethnographic and market research techniques, periodic Living Standards Measurement Surveys conducted every three years (in 2002, 2005, and 2008) followed by annual subsample surveys (in 2003, 2004, 2006, and 2007), ${ }^{8}$ and the Demographic Health Survey conducted from October 2008 to April 2009. ${ }^{9}$

These data contain not only rich georeferenced information on income and consumption expenditures, on background characteristics of education, employment, residential histories, migration and media exposure but also full information on retrospective reproductive histories, fertility preferences, knowledge and use of family planning methods, marriage and sexual activity, breastfeeding and infant feeding practices for all women in the household as well as on childhood mortality, which allow obtaining a full picture for the analysis of fertility behavior in Albania.

Social anthropologists have tended to turn away from the use of surveys and statistics. Concerns that quantitative data are too thin, too decontextualized, or too politically suspect all contribute to the decline of survey data in anthropology, and sometimes with good reason. However, some questions are best addressed with quantification. My intention here is neither to turn away from close, cultural investigation of specific people situated in place and time, nor am I unconcerned about the assumptions and limitations of demography. As with any kind of data, however, their reliability and validity 
are important concerns. In particular health statistics produced before 1991 by the former regime in Albania must be assessed critically, due to the overriding practice of encouraging the practitioners to falsify data to make the administration appear successful. Contradictory conclusions of studies often arise from different time, context, and types of issues investigated. Various methodologies used may also account for some differences. Most studies use cross-sectional data, while longitudinal data have found only limited use, despite their dominant position in many areas of population research. Often the lack of coordination of rapid assessment projects has also led to controversy between reporting groups as to the accuracy of one another's data.

Still, survey data are susceptible to some more important types of bias, commonly called sampling, nonresponse and response errors. The usual solution to sampling error in quantitative analysis, and the one followed by the Albania Surveys, is random sampling, whereby every person in some geographic area has an equal probability of being selected. Nonresponse error can be large when a large proportion of people refuse to answer the survey, as they may have different characteristics than do the people who are included, but published estimates show that none of the Albania Surveys had refusal rates above a few percent. By contrast, response error when the person answering the survey gives inaccurate, inappropriate, or irrelevant information is a source of bias that is likely to be important.

Therefore, a major contribution in this kind of studies should be seen the use of standard and multisited ethnographic methods within fieldwork, the corner stone of anthropology as an empirical social science. To this aim, the analysis presented in this article is informed by a broad spectrum of original field data and primary sources, from archival data recorded since the first half of the nineteenth century to a series of ethnographic accounts covering a large portion of the Albanian-speaking areas and diasporas. Essentially, the overall available data are completed with the background of my own firsthand knowledge during residential fieldworks, one year in 1976 in High Opar and four years from 1981 to 1985 in Low Mokra, both remote areas of southern Albania. I also did systematic fieldwork researches in several Albanian areas between 1985 and 1990 in the framework of the Institute of Popular Culture in Tirana, including the areas of Devoll in the Southeast, Has in the Northeast, Lura in the North, and so on. ${ }^{10}$ Since I continued throughout the 1990 s to visit occasionally the areas I had got to know initially, I also gained a longitudinal perspective on the impact of social change on the communities. In addition, I had the opportunity to do fieldwork research in Kosova during 2001 and 2002, thanks to a grant from the Open Society Institute of the Soros Foundation, Budapest. ${ }^{11}$ Since the early 1990s, I have been also able to do extensive research among Albanian migrants in Western Europe, specifically in France, Belgium, Italy, Greece, England, or Switzerland. The acquaintance with two relatively compact Albanian communities, settled at least since the 1950s in Sucy-en-Brie in Paris area and in Brussels, respectively, and somewhat related to each other by intermarriage, turned to be of particular interest as they have conserved more than in Albania certain patterns of cultural forms and social behavior.

Cross-culturally, one of the most important and universal aspects of the life course is reproduction, while the emergence of human cultural capacity has allowed for remarkable variability in the timing and sequencing of childbearing vis-à-vis other events in the life course, including marriage. There are well-documented historical and cultural differences in total fertility, fertility timing, and fertility preferences around the world. Although the variability in behavior is clearly evident, the precise cultural mechanisms underlying such variability are less obvious. Anthropologists, demographers, and economists have extensively debated the role of culture in determining these differences in fertility preferences and behaviors. ${ }^{12}$ Economic, biological, and evolutionary approaches emphasize resource availability and constraints as the primary determinants of contemporary and historical differences in fertility. ${ }^{13}$ Debates on the cause of this variation have been vociferous and heated, and it seems great moral stakes rest on whether such disparities in fertility and family formation are the product of "culture," or relative socioeconomic disadvantage, or even a behavioral adaptation to ecological risk. ${ }^{14}$ 
Within anthropology, common approaches to characterizing cultural differences have focused on describing mean or modal distinctions, such as the cultural differences in child-rearing styles described in the now classic "Six Cultures" study. ${ }^{15}$ Such techniques first describe a general domain of life, then identify a modal model, and finally compare groups and individuals with respect to the endorsement or enactment of this model. The results of such analyses have been highly informative, yielding predictive power for both mental and physical health outcomes. However, such analyses tend to hang over at the broadly descriptive level, leaving one to wonder about the specific content of these models and their relevance to the individuals and groups for the outcomes under consideration.

One of anthropology's central concerns has been how cultural or group differences in behavior, experience, and ways of seeing the world are created, maintained, and reinforced. Psychological anthropology has contributed to these investigations through its description of group differences in shared cognitive and emotional structures or cultural models that underlie these observed behavioral differences across cultural groups. ${ }^{16}$ Contrasting with the conception of cultures as composed of reified symbols and their meanings, serving as public currencies in the conduct of social affairs, ${ }^{17}$ these findings reinforce the understanding of culture as carried in individual minds,${ }^{18}$ and direct our attention to the processes by which cultural diversity is formed, moving us further from the flat, descriptive essentialism of earlier perspectives on culture. The point with cultural models is not to psychologize the study of culture but to lay a foundation for a view of culture as working through the interaction of shared cognitive structures and cultural institutions that activate those structures to varying degrees.

Parents' culture-specific models of child rearing, for example, are associated with psychological, biological, and behavioral differences in child development, ${ }^{19}$ a pattern I also found while exploring the constraints of age-grading practices to the cultural construction of personhood in Albanian context. $^{20}$ Actually, not only cultural models influence fertility decisions by filtering perceptions of resources and framing relevant trade-offs for having children versus delaying or foregoing childbirth, ${ }^{21}$ but cultural models and resource constraints may also interact, or even expressed ideals regarding the timing of childbirth may break down in resource-poor and unpredictable environments, replaced instead by forces of serendipity and chance. ${ }^{22}$

A central feature of this debate concerns the degree to which such strategies may be conscious and culturally specific adaptations to resource deprivation, shortened life expectancy, and marriage pressure. Recent work on cultural models indicates the need to uncover the specific content of models and to explore the possibility that individuals and groups simultaneously espouse multiple models for the same domain of life. ${ }^{23}$ In summary, the current state of knowledge begs the question of whether and how differences in cultural models underlie cross-cultural differences in fertility timing. Historical and contemporary narratives as much as different quantitative data tell overlapping but not necessarily the same stories, which illustrates the utility of mixed methods and analyses to triangulate inferences about the role of cultural models in human behavior.

In this study, careful analysis of data from all available sources is intended to produce a collection of "cognitive maps" that must represent how people think and feel about reproductive matters and how these thoughts and feelings are related to each other. If people always think and feel simultaneously, attitudes and knowledge are inseparable and elicitation of emotions and thoughts must not be separated. This suggestion is based on the hypothesis that all humans think in metaphors and that to find the deep structure of a culture to understand behavior, it is necessary to elicit and explore in depth the metaphors related to the topic of interest. ${ }^{24}$ In keeping with the emphasis on eliciting respondents' own views and understanding how people think about the topics under discussion, people's comments can be regarded as both local and personal knowledge and feelings. 
Some group differences in behaviors may not be supported by group differences in modal cultural models but, rather, in the distribution or relative emphasis of multiple models for any particular domain of life. In addition, it must be recognized that in a local community there are many voices and many perspectives that must be heard in their own voices as much as possible. This suggests that one facilitating factor for early and high fertility may be not a specific cultural model for early childbearing but, rather, a degree of allowance for childbearing to occur at multiple points in the life course. Again, such an allowance may be not facilitated by the existence of a specific culturally mediated model of extended family and community structures that allow for distributed child rearing but, rather, by differences in the distribution, organization, and weighting or salience of idiosyncratic variation in cultural models and values.

\section{Background Review}

In an effort to seize the "authentic" traditions and "popular" cultures such as they were supposed to have "really" functioned in a society of official ideology, Albanian scholars were devoted primordially to description. As I showed elsewhere, ${ }^{25}$ their best publications are certainly not contributions to the anthropological or sociological theories, but belong to the ethnographic and folkloric genre, based in the empiricist descriptive norms of the communist and nationalist ideology in Albania or evolved during the relative cultural autonomy in Kosova. There are few references to theoretical work and never are asked questions of distinction between real practice, ideal system and ideal typical process, between behavioral norms and rules of what most people actually do and ideal norms and rules for what people ought to do and how they ought to behave.

Apart from they typically indulged in citing national sources produced and reproducing each other within the national context only, the main body of sources in such nationalist academic literature usually consisted of classic international studies from the mid-nineteenth to the mid-twentieth century only, largely influenced by the pre-1950s German Kulturhistorische Schule, to which belong as well the historical Italian missionary studies, and a number of classical anthropo-geographical texts of Albanian culture, all of the early twentieth century. In general, the typical canon of Albanian nationalist historiography and ethnography usually referred to international texts only as long as they served the ultimate goal of constructing national specificity and a particularly ancient origin of national culture. These studies tended to be affected by what Roland Barthes called the "virus of essence, $" 26$ very much historically orientated toward the folklorist paradigm of Reliktforschung, ${ }^{27}$ concerned with a search for the remainders of ancient times.

Whereas the Western tradition of scholarship is deemed to be more sophisticated, the problem is that some of these studies often have a definite moral-ideological position and orientation on Albanian rustic patriarchy, which is very much in line with the Western academic "good citizens" for whom "patriarchy" is the ideological bogeyman just as communism is for the neoliberal freemarketers. In the last analysis, this may have unduly undercut a more important potential to generate more informative insights into the specificities of the cultural logic of the traditional Albanian patriarchy. The irony of contemporary Western social theory is that the interpretations have often only rediscovered or, to say the least, come in very much sympathy with those of local Albanian scholars during the communist period. When the latter were trying to exemplify what they called zakone prapanike, "backward customs," and other social themes "from the past," that is, before socialist reforms were introduced, they have not hesitated to label rural social relations as "patriarchal" and they were very aware of the close relationship between village customs and observances such as birth practices or wedding ceremonies and other aspects of the local social order.

However, more often than not their efforts are ignored, and in this attitude the least can be said to be a lack of mutual awareness or cooperative dialogue, since a related problem might be at least this regrettable tendency of British and American publishers to tolerate a good deal of literature written 
by authors who are not fluent in the necessary languages or who make a deliberately selective use of sources, as I showed in details elsewhere for some other of such studies. ${ }^{28}$ As a result, various painstaking efforts have provided more or less invaluable surveys of the details of particular Albanian cultural inventions, but the main interest seems only to be in correcting either the mistakes of Western specialists or the presumptions of local scholars on one or another point of details.

To be sure, many recent studies may show a more concern for historical source criticism and a higher level of academic sophistication. In particular, contemporary German and Austrian historical studies have developed in the last decades a strong historical research specialization, especially at the universities in Vienna and Graz, and produced a series of publications on the Albanian and wider Southeast European kinship structures, the composition of traditional complex family systems, and the principles of household formation in an European comparative perspective. ${ }^{29}$

Nevertheless, they seem still reproducing old patterns of cultural particularism and cultural determinism, probably not totally liberated from the old culturalist legacy of the German Kulturhistorische tradition from which official communist and nationalist scholarship seem to have emerged in Albania and in the Balkans. Well versed as they are in using the empirical evidence from a wide range of sources, they endlessly try to divide and typify cultural areas in Europe and in the Balkans, reminiscent of the old anthropo-geographical Kulturkreislehre. These typologies proceed along the lines of purely demographic criteria confined to the evaluation of quantitative data. In doing so, whatever typology restricts itself to those characteristics which, as a rule, can be found in sources such as birth, marriage, and death registers or census lists.

A theory developed in the mid-1960s, for instance, distinguished between two historically different marriage patterns, drawing an imaginary line across Europe running from St Petersburg in the North to Trieste in the South. ${ }^{30}$ The hypothesis was further elaborated in the 1980 s to introduce patterns of household formation into the equation of marriage patterns. ${ }^{31}$ The hallmarks of the two different systems were a high age at marriage and a dominant presence of simple or nuclear family households in the West and a low age at marriage and extended or multiple family households in the East. Finer divisions have been provided to further distinguish between four different sets of tendencies in marriage patterns and domestic group organization, assumed to be located in the West, the Center or Middle, the South or Mediterranean, and the East of traditional Europe. ${ }^{32}$ These hypothetical sets would be based on as many various criteria as the occasion and method of domestic group formation, procreational and demographic criteria, criteria of kin composition of groups, or criteria of organization of work and welfare.

In this vein, recent promoters have drawn attention to the fact that, within the area of the supposed Eastern European Marriage Pattern, it was above all the Balkans that differed markedly from the rest of Europe. A specific "Balkan family" pattern is identified and four distinctive household formation patterns are further distinguished in Southeastern Europe, related to existing inheritance systems. The pattern is said to have spread in an area of the western and central Balkans, covering parts of Slovakia, Hungary, Romania and Croatia, most parts of Serbia, Bosnia and Herzegovina, Montenegro, Western Bulgaria, Macedonia, Kosova, Albania, Northern Greece, parts of Peloponnesus and large islands like Crete, Corfu, and Cyprus. ${ }^{33}$

On the whole, there appears to be a consensus that at a high level of aggregation, these anecdotical typological models could have some analytical value as a simple hypothesis. ${ }^{34}$ Largely implicitly, however, the distinction of these different marriage patterns and household formation rules in Western and Eastern Europe referred in the very first place to the rural population and were closely tied in with systems of property devolution through successive generations in agricultural societies, where land provided the principal and often only source of the means of existence for households. Access to land was crucial for the economic independence of newly married couples, which played such a central role in the purported Western European Marriage Pattern, and therefore people tended to postpone marriage until they had reached the age at which they could assume headship of the 
household or inherit the land of their parents. In the East, by contrast, economic independence was not a prerequisite for marriage, and therefore people tended to marry young. The question then becomes whether an apparently similar phenomenon at different points in time, in this case whether a lower or a higher average age at marriage, is in fact linked whether to a set of similar or different ecological, social, economic, demographic, and historical factors, or perhaps it is an expression of a set of culturally coded values that allegedly tended to perpetuate themselves over time.

The so-called Balkan Family pattern, for instance, is supposed to be characterized by equal partible inheritance and a multiple-generational household cycle rather than an individual life cycle. In addition, while in a northern variant scarcity of land and high population density seem to be the decisive factors, the southern variant turns to be characterized by a distinctive patriarchal cultural background, where institutional factors and ideological elaborations have got muddled up in what is blatantly reified as "Balkan patriarchy." "35 Not surprisingly therefore that all this became good to characterize these peoples as caught up into their agnatic dyadic relationships or their supposed "tribal" organization and "tribal" laws, including not only complex family structures and especially many children but also predatory warfare, blood feuds, honor killings, birth customs and ancestor worship, cradle betrothal and bride purchase, and other "savage" customs of the like.

In this connection, a general claim is advanced by many travelers and scholars alike according to which, consistent with such a cultural pressure must also correspond a low age at marriage, for this is the best means of ensuring a high number of children. Because of the lack of reliable statistical data until recently for the nineteenth and beginning of the twentieth century, the analysis of marriage patterns and household structures in Albania has so far been based on the records of foreign travelers, who all indicated a very low age at marriage for both men and women in Albania. Several publications mention in the middle of the nineteenth century for the remote regions of Northern Albania a "relatively low age at marriage for women," while for Southern Albania, ages at marriage of twelve years for girls and of fifteen years for boys are recorded very early. ${ }^{36}$ In the beginning of the twentieth century, ages at marriage of thirteen years for girls and of fifteen years for boys are recorded again. ${ }^{37}$ Even in the first half of the twentieth century, early anthropologists reported a low age at marriage, especially for women. As Carleton Coon observed, "in northern Albania girls are married as soon as they come to sexual maturity and begin bearing children as soon as they are biologically able; there is no time of peace." 38

Another issue that has to be questioned seriously is the related claim about the high number of joint family households in the Albanian upland with sixty and more members and the general assumption that Albanians did not divide their households for generations. Indeed, recorded cases of Albanian and South Slavic extended family are repetitiously considered as one of the famous types of household that has amazed scholars and travelers for its size, all vying with one another to find out the "largest family in Europe."

\section{Empirical Evidence}

The usual explanation for a low age at marriage is again this kind of resort to primordialism that characterizes anthropological works on Albania, namely, the urgent need for children in the milieu of the so-called Balkan patriarchy, ${ }^{39}$ which has been already the standard view of Albanian ethnographers. ${ }^{40}$ Marriage behavior is related primarily to the rules of household formation in the Balkans, especially to patrilocality, the main justification of which was the common male ownership of property. Having a male heir was considered very important and the men in any household were interested in marrying young girls, as the period of fertility was longer and they had better chances of giving birth to a son. Hence, to complement the system, an early age to "maximize" female fertility must have been a crucial prerequisite for a successful marriage. This is why, for those scholars primarily concerned with area typologies, the marriage patterns in Albania would necessarily fit into 
the "Eastern European marriage pattern" characterized by a low age at marriage and a virtual lack of celibacy, even though it can be refined over and over again according to one or another criteria emphasizing purported cultural characteristics of a Balkan patriarchy.

Ethnographic accounts of social morphology and gender among the Southeast European rural populations have systematically indicated the marginalization of women in the cultural life of the domestic group and the community. ${ }^{41}$ Especially the customary-based North Albanian society as it existed till the first decades of twentieth century was in many ways what could be properly termed "patriarchal," that is, as I showed elsewhere, ${ }^{42}$ a society that used to put strong emphasis on the inferiority of women and acknowledged exclusive male rights and authority above those of women. While South Albania is to an extent more cosmopolitan, particularly in the communities of these distinctively rural and mountainous areas of North Albania and Kosova, as in similar settings of Bosnia, Montenegro, Serbia, Macedonia, and Greece, such patriarchal values have persisted more than elsewhere. ${ }^{43}$ The extent to which Albanian women resented ritualized female deference and a subdominant position, as in other Balkan societies, included marrying into a male-controlled household, carrying out heavy domestic or agricultural duties, and limiting herself above all to childbearing and child rearing.

In the literally typological view, however, it seems that the cultural myths and ideologies associated with patrilineality are conflated with the actual practices of patriarchy. In my view, the authors too easily assume that the patriarchal language and discourses that symbolically support patrilineality result uniformly in outcomes and practices that are simply patriarchal. While I do not dispute the notion that Albanian family system was patriarchal, this standard view conflates patrilineality and patriarchy and seems to assume that evidence of patrilineality is evidence of patriarchy. Arguably, the historical, ethnographic, and demographic evidence must be examined against a much more nuanced theoretical perspective to sort out some of the complexity of patrilineal kinship structures and patriarchal ideologies and practices. To begin with, the extreme view of low age at marriage is not supported by the empirical evidence.

The analyses of the age at marriage based on the data of the 1918 Census show a surprisingly high age at marriage for men and a higher-than-expected age at marriage for women. These data allow us to extrapolate the singulate mean age at marriage, which is calculated by the proportions of single people at certain ages. According to this extrapolation, the mean age at marriage resulted in 18.3 years for women, with 19.8 years in urban and 18.1 years in rural areas, whereas the mean age at marriage for men was 27.0 years, with 30.2 years in urban and 26.6 years in rural areas. ${ }^{44}$ The age at marriage of women for most of the settlements was at about 20 years, while at an age of 35 years, 19.6 percent of men were still unmarried. Shkodra City scored strikingly the highest ages at marriage for both men and women in comparison with the other cities: 20.9 years for women and 34.2 years for men. These figures seem to be confirmed by anthropological studies in the early 1930, which have reported in northern Albania a delay in the marriage of men. ${ }^{45}$ They are not only confirmed but relatively underestimated with regard to official census data in the 1930s, which show high proportions of men (50 percent) ever married at ages 25-29 and even higher proportions of women (58.7 percent) ever married at ages $20-24$ in Albania. ${ }^{46}$

Not surprisingly, the tendency to look everywhere for area typologies might still trigger certain young scholars to provide as much refinements as they can. Thus, the findings related to the urban marriage pattern are declared to correspond to the supposed Mediterranean set, while the marriage pattern in the villages is claimed to correspond to the more classical Eastern European pattern. ${ }^{47}$ On the whole, however, if there is a need for area typologizing, the male segment of the Albanian population would almost fit into the so-called Western European marriage pattern, insofar as the percentages of single males in their twenties were almost as high as in Western Europe and considerably higher than in Eastern Europe.

But I do not regard myself as bound by typologizers' refinements here. The very low ages at marriage recorded by travelers and ethnographers in the nineteenth century and in the beginning 
of the twentieth century cannot be confirmed. There might have been a rise in age at marriage since the middle of the nineteenth century or there might have been many cases of young girls already being married at an age of fifteen years. However, the low ages at marriage recorded in the nineteenth century maybe the lowest at which marriage actually happened and no averages or they might have been some sort of ideal reported to foreign travelers and researchers, but an ideal that was simply met by a minority of women in reality. The relatively high age at marriage for men is again in complete contradiction to the reported low ages at marriage and to the assumption that a low age at marriage was needed for ensuring the continuation of the patrilineage.

What is important here is that the combination of the different age at marriage between men and women and the uneven sex ratios influenced the large age difference between spouses, the mean age difference being 11.5 years, while it rose to 18.7 years for second wives and 30 years for third wives. $^{48}$ This wide and sometimes even very wide age gap between husband and wife facilitated the existence of patriarchal practices and ensured male domination within the household very effectively.

A related issue is also the age at marriage as a crucial element in the formation of a household. Under the so-called Eastern European Marriage pattern, an assumed early age at marriage was supposed to have favored the formation of joint family households in the absence of neolocality, as shown in the Bulgarian case. ${ }^{49}$ Such complex family households would have consisted of couples of two generations, insofar as newly married spouses as a rule would still be too young to set up a household of their own and would therefore coreside with the parents of one of the spouses.

There is considerable disagreement on the origins and functions of the extended family structures found in Southeast Europe. Most research was meant to prove or to reject the notion of the predominance of this kind of households in this part of Europe. ${ }^{50}$ The question remains, however, whether the families were really larger before. This has been doubted by many and contradicted by historical evidence on the average size of the families. Statistical material on family size on various villages within Serbia has convincingly demonstrated that the average family was actually quite small, while cross-cultural studies on family and domestic groups have showed that nowhere is there a bona fide case of more than six members to an average household, confirming the fact that extended families represented extremes in the statistical sense. ${ }^{51}$ In the case of Albanian family structures, the bulk of historical evidence clearly shows that the average size of rural families prevailing in most territories populated by Albanian-speaking people was relatively small. ${ }^{52}$

If the domestic family was never extended in any degree, most research on family and household structures in the Balkans is dealing with what has been labeled as the "myth of the large extended family in former times." Indeed, much of the literature seems to have dwelt on exceptional cases which are described in detail. Such an approach does not help us understand the conditions under which the majority of the people lived. Exceptional cases of large households must therefore be considered as a curiosity to visit, but as a statistical extreme they become an anachronism, and as such not relevant, even though in such areas where a large family unit meant strength, through biological expansion, any small family may become an extended family of this sort. Actually, with some few exceptions, ${ }^{53}$ seldom is any account taken of the possibility that a household can be large at one time and small at another, in particular that households may have what is usually discussed as the developmental cycle in domestic groups. ${ }^{54}$

What often area specialists have overlooked is precisely the importance of the development cycle for the size of a family, whereas they deal with the "average family size" or discuss the distribution of family sizes implicitly as if these were representing different types of families. Family extension or division must have represented a strategic choice of separable family units (hise) that wanted to whether remain together or set up separately on their own right. Given that there is necessarily a certain process of growth and split within families of a particular community, the average family cannot be promoted as the normal family nor be accepted as the type which the majority of families 
represented. Whether it is correct under any conditions to say that the "normal family" is nuclear or extended is a matter of definition. It is very possible that the patterns observed in Southeastern Europe are pure expressions of regular family development cycles extending over a certain period of time. It may be that what appears in a synchronic perspective as different types of families are simply stages in the same process.

But what is more, the figures recorded in the 1918 Census clearly show that there was simply a demographic constraint, which obviously limited possibilities for the formation of complex family households in Albania. The high age at marriage actually must have lowered the proportion of people living in complex family households, since the late age at marriage of males led to a large generation gap that consequently limited the father's chance to stay together with his married son in an extended family, while the small number of children must have further limited the chance of establishing a joint family household. ${ }^{55}$

Demographic constraints did not only affect the formation of multiple family households but the high age at marriage coupled with high mortality rates also decreased the years a son could live with his father. While the wide age gap between husband and wife facilitated the existence of patriarchal practices and ensured male domination within the household very effectively, the effect of a high age at marriage and a large age gap between the spouses was generally for fathers to lower their probability of living with a son and thus having a male heir. The crucial problem is mortality, and not only males died before they could marry and produce a male heir, but high infant and childhood mortality rates, poor health, and high infertility by unusually high levels of venereal disease, ${ }^{56}$ also lowered the chance of having a surviving son, once men were married and became fathers.

In some cases, many women remained childless at the end of their reproductive years and it was highly probable that given the high age of marriage, especially for urban men, and the high mortality rates in Albania, few fathers lived to see the day that their sons married. They were either already dead or died in the first years after their son's marriage. Indeed, sons lost their fathers quite early. At the age of fifteen years only half of them still had a father, ${ }^{57}$ and there are more troubles with these findings. The 1918 Census does not indicate how many children were born in each family, only how many were alive and resident in their parents' household on the census date. Astonishing as it might seem, in the national sample, there was a relatively high proportion at 37.2 percent of young married couples without children. They had no children, their children had not survived, or they only had daughters who had left on marriage.

Definitely, at the end of the nineteenth century and at the beginning of the twentieth century, it must have taken quite some time for Albanian men to father living children. While half of the men were living with a son already at an age between 25 and 30 years in Serbia, only at an age of 45 years this was so in Albania and only when men had reached 65 years did 70 percent of them have a (surviving) son: they had a mean of 1 (surviving) son in the same household at the age of just 45 years and the maximum was only 1.5 sons at the age of 65 years. ${ }^{58}$ Arguably, if the highest percentages were reached later in life, there were very few older people living at that time.

Again the standard view, much more affected by irregular variation due to the small number of recorded cases, is massively overestimating the number of men who were successful in producing a male heir. Based on a preliminary analysis of the data from the 1918 Census, ${ }^{59}$ one must be right to consider that at least 16 percent of all men at that time failed in their attempt to produce a male heir and that only 3 out of the 4 of all men who reached adulthood were able to secure the continuation of the family in male line.

\section{Fertility Transition}

By the end of the Second World War, Albania had the highest fertility in Europe, with an average of about six births per woman, but in the 1970 s there was a steady decline, with a total fertility rate of 
less than four in 1980 and just over three children per woman in 1990. Social and demographic settings for a further fertility reduction in Albania have been reinforced since the early 1990s, especially with regard to the availability of contraception and abortion. A continuous reduction in fertility was confirmed by both aggregate vital data and individual survey data at a rate of 2.2 children per woman in early 2000s. The Demographic and Health Survey conducted in 20082009 showed a total fertility rate of 1.6 children per women for the three years preceding the survey, while according to official reports from the Albania Institute of Statistics, the total fertility rate is even estimated to have further declined to just 1.4 children per women in 2008, confirming a level of fertility in Albania falling below the replacement level, similar to other European countries.

However, it is interesting to note that during the $1950 \mathrm{~s}$, the total fertility rate rose further to reach a peak of almost seven children per woman by 1960 . This may well mirror the "baby boom" experiences of many European countries at the end of the Second World War. As one of the countries with the highest per capita losses, it is not surprising that fertility increased in Albania immediately after the war. The point is to explain how the postwar baby boom started, like in no other European country, from such a high underlying rate.

A possible interpretation of this trend is that the period immediately before fertility decline can be one of significant upward change, which represents a pre-decline rise in fertility of the kind suggested to be a widespread characteristic of fertility transition. ${ }^{60}$ To explain the pronounced peak that typically precedes a sustained period of fertility decline similar to the rise in period fertility during the 1950s and 1960s in Albania, a number of variables are identified, which seem especially important in the context of pre-decline increases. Major pre-decline increases have resulted above all from a marriage surge at younger ages combined with increased marriage at later ages reflecting substantial gains in mortality.

Today attention to marriage focuses on the considerable evidence that the age of women at marriage is rising, with accompanying steady increases in proportions of women married at later reproductive ages and modest decreases in proportions of women ever marrying. But considering Albania, the most interesting feature is that during the $1950 \mathrm{~s}$, there were large increases in the proportions reported as currently married at younger ages, and especially in the 15-29 age range, where the potential fertility impact of change is high. In addition, proportions of women never married at ages 15-19, 20-24, and 25-29 generally declined, as did estimates of the mean age of women at marriage. Indeed, according to official census data, the marriage rate was on a very low level at $6 \%$ in the late $1930 \mathrm{~s}$, but it almost doubled at $11.8 \%$ in the early $1950 \mathrm{~s}$. In addition, whereas from the 1930s to the late 1950s the proportion of women ever married at ages 15-19 years more than doubled from 20 percent to 46.5 percent, the proportions of women ever married at ages 20-24 and 25-29 declined moderately from 58.7 percent to 40.9 percent and 18.6 percent to 8 percent, respectively. ${ }^{61}$ Only in the 1970 s, did these trends in marriage patterns begin to reverse.

Clearly, if the precursor of fertility decline is normally an initial rise brought about by an increase in the marriage rate, an increase in the proportions of women married at younger ages and, of course, an increase in the numbers of women living the whole of their fertile period thanks to the decline of mortality, the first reaction is that the related marriage surge at younger ages could not have taken place in Albanian context where marriage was always assumed to be both very early and universal. Perhaps, the characteristic of early and universal marriage in Albania is often attributed a little too automatically. The suggestion arises that in Albanian context, significant proportions of younger women traditionally were not married and that the age at marriage must have been higher than generally assumed.

Perhaps more importantly, despite the dramatic reduction of fertility, the mean age at marriage has changed very little. It is important to note that, according to the data from the Reproductive Health Survey in 2002, less than half of the women (41 percent) had been married before reaching 22 years of age, which is reflected in a mean age of 21.9 years at first marriage. This is also confirmed by official data from the Albania Institute of Statistics that show a mean age at marriage 
on average from twenty-one to twenty-three years for women in the period between 1950 and 2007. It dropped from 21.8 years in 1950 to 20.7 years in 1960, increased to 21.2 years in 1965, 22.4 years in 1990,23 years in 2000 and exceptionally 24.1 years in 2001 , for only to drop again to 22.4 years in 2007. The same applies for men, with an increase of the mean age at marriage on average from twenty-seven to twenty-nine years in the period between 1950 and 2007.

Definitely, compared to the mean age at marriage of 18.3 years for women and 27.0 years for men in 1918, a moderate increase of 4 years for women and 2 years for men in the last 100 years or so, given the dramatic decline in fertility rates in the last 50 years, demonstrates again that the correlation between a low age at marriage and the urgent need for many children as the distinctive feature of a supposed Balkan Patriarchy cannot be confirmed. Otherwise, all other things been equal, with the dramatic improvements in education, and in female education in particular, the marriage pattern would have run into typological troubles, at least with an uneven rise in the singulate mean age at marriage for both men and women.

The standard view continues to consider Albania exclusively as a country that has been, and to a certain extent still supposed to remain, a traditional and patriarchal society. In particular, the social organization is regarded as based on the same patriarchal system that disadvantaged women in all aspects of their social life. The social structure is still believed to be basically tribal in the north and semifeudal in the center and south of the country, with kinship and descent playing central roles. The basic social unit is still supposed to remain the extended family organization dominated by strong cultural and traditional values common to a male-dominated society. This patriarchal social and family system is further claimed to have affected a number of the determinants of fertility, such as large families, universal marriage and first birth, early entrance into marriage for both men and women, childbearing only within the marriage, restricted access to contraception and abortion, and many others.

The same applies to the pronatalist philosophy of the communist government, which is claimed to have been so widely accepted only because it played into an already pervasive positive attitude toward childbearing. In fact, women's primary role during the communist years remained that of procreator. The focus simply shifted from production and reproduction for the men to production and reproduction for the state. Thus, women are considered to have not received increased autonomy and decision-making power with respect to their reproductive capacity, even though they attained status and increased power in work and education.

Pursuing similar endeavors of typologism, over and over again, Albania is said facing a contrasting experience, something which in one side may reflect the social and economic effects of change happening in most of the East European countries, but on the other side it is also reflecting emphasized patterns of family formation in South European countries. Thus, typologizing refinements aim at indicating that, similar to East European countries and in contrast to Southern European countries, the economic and social crises of the 1990s affected the timing of birth, but in Albanian case the timing of second and third births, whereas the timing of the first birth was not affected because Albania is considered to remain traditional in family values. ${ }^{62}$ In relation to the patterns of fertility behavior happening in a time where Albania faced huge political and economic changes, it is assumed that perhaps "modernity" and economic constraints must have affected the number of children, whereas a "traditionalism" of cultural norms and values is assumed to have persisted for the onset of family formation.

The question of why do some women end up with more children than they wanted occupied much of demography in the second half of the twentieth century, and the commonly given answers are a lack of access to contraception and a lack of autonomy. ${ }^{63}$ By contrast, despite the lack of contraceptive knowledge or provision and the pronatalist policies pursued by a powerful central government, the dramatic decline in Albanian total fertility is all the more surprising. Even more striking is the fact that, without access to modern contraception and highly restricted access to abortion, smaller 
completed family sizes and fertility declines must have been brought about by means of traditional forms of birth control and family planning, which require a high degree of motivation for successful use and, perhaps more importantly, the cooperation of the man involved.

This leads us to move away from the standard framework of thinking Albanian society and culture in the terms of traditional patriarchal values that are claimed to have persisted in Albania in spite of the significance of education and urbanization during the communist regime, followed by further modernization in the last two decades after 1990. A reexamination of the impact of gender relations and in particular the extent of women's "autonomy" in the context of rapid fertility reduction in Albania is all the more interesting because of its increasing centrality in reproductive policy. More and more, when unwanted childbearing is the problem, women's empowerment is seen as the first solution. Yet, women's autonomy appears to be a difficult concept to formalize or compare across contexts, ${ }^{64}$ as a number of scholars have proposed that this concept of Western liberalism translates particularly poorly into the experiences and self-representations of many women. ${ }^{65}$

Of course, despite the dramatic reduction of fertility, discussions with Albanian women today suggest that marriage continues to be regarded almost universal and levels of nuptiality continue to be seen as high as in the past, a feature that is deemed to be characteristic of the classical Eastern European Marriage Pattern either in urban or rural areas. As with women in other countries of the region, Albanian women typically marry and begin families to initiate and complete childbearing at a relatively young age, insofar as childbearing remains a constant concern even in a rapidly changing society. In Albania today, women are seldom heard to say that they are setting aside family priorities for career options. They often do not know what their next job will be, or even if they will have one. However, they do know that they will have a family and be a mother.

In addition, in the realm of everyday choices about childbearing, many Albanian women may still admit that their husbands' decisions supersede their own. Insofar as autonomy refers to the right or power to make choices about her life or future, women in Albania would deny that they had any kind of autonomy. However, to better understand women's autonomy and gender relations in Albania today, we must look at how both men and women actually describe reproduction choices. Even though the results from a qualitative research that uses ethnographic and projective cognitive elicitation techniques aimed at uncovering a culturally shared cognitive domain must be examined at another time, it is worth mentioning that a more holistic understanding can be obtained that is as close as possible to the ways that people actually think about family planning, its place in marriage and relationship to childbearing, and how these concepts are influenced by gender roles and status.

A similar picture is also confirmed by the data from the Demographic and Health Survey in 2008-2009, which show that there is considerable desire among Albanian women to control the timing and number of births, even though fertility preferences are closely related to the number of children a woman has. Among currently married women, only about 8 percent of married women would like to have a child soon or within 2 years, about 9 percent reported that they would like to wait 2 years or more before the next birth, and a significant proportion of 73 percent report that they do not want to have another child at all or they are even sterilized, while the remaining women are uncertain about their fertility desires or say they are unable to get pregnant.

On the whole, it can be said that in Albania today there appear to be two types of marital relationship independent of geographic distribution. A few marriages show enactment of traditional gender values and ideal norms and rules for how people of each gender ought to behave. These marriages are characterized by much less empathy and closeness between spouses with husbands being strongly dominant and expecting wives to obey their commands. However, by far the most common relationship is characterized by empathy between the spouses, love, emotional closeness and intimacy, concern, mutual trust and respect, and joint decision making, even though the husband may tend to slightly dominate. 
Among other so-called patriarchal cultural values that must be reexamined at another time is also the influence of son preference to fertility and childbearing. It is important at this point as always to take into account that behavioral norms and rules of what most people actually do, and which are often recorded in census data and vital statistics, often contrast with ideal norms and rules for how people ought to behave, and may conflict with other behavioral norms, so that several different courses of behavior may be normatively justifiable. Both Albanian women and men are more likely to prefer sons but both are also likely to try for a daughter, especially after a son or they may be even likely to say that their female child was wanted. This is true despite their apparent overwhelming son preference, despite women's relative lack of autonomy in reproductive decisions, despite the fact that women rarely report challenging their husband's decisions, and despite the fact that they rarely report agreeing with their situation in family and society.

\section{Ideological Fabrication}

If the standard view of a low age at marriage assumed to be needed for ensuring the continuation of the family and patrilineage, altogether with the related views of the successful reproduction of many male heir children and the development of complex family structures in Albanian context, flew in the face of empirical evidence, these views cannot have been triggered but by ideal-typical and ideological processes. The informants must have provided data that reflected more of an ideal situation than reality, inadvertently contributing to the "myth of many children" and to the "myth of the large extended family" in former times in Albania, which has been thereafter taken over by mass media and massive faux-scholarly publications to find out the rationale behind the recent excesses of nationalism and ethnic cleansing in the Balkans. But whatever informants may tell us, we must not loose sight that we are observing what exactly they can manage to do with ideological schemes when their prestige is at stake. If there is systematically a general concern for the informant to provide the observer, and subsequently for the observer to provide the reader, an official or respectable version of the facts, this undoubtedly reveals something of the nature of cultural self-awareness as well as of the politics of observation. Indeed, this is nothing more than what Maurice Bloch called the expansion of ideology into something that misleadingly looks like an interpretation of the world. ${ }^{66}$

According to Albanian traditionalist cultural discourses, it was very important for a woman to bear sons and, as I showed elsewhere, many efforts were made to be successful in this respect. ${ }^{67}$ The related issue of couvade is also examined elsewhere, ${ }^{68}$ whereas that of sworn virgins, incoming husbands and shared wives must be examined at another time. ${ }^{69}$ A woman's childbearing had a direct effect on her own social status. As in other Southeast European societies, most Albanian data from North and South show that only after having given birth, especially as the mother of sons, a woman would be recognized as a fully fledged wife and secure a place in the group, bound to it through a blood tie. ${ }^{70}$ I showed elsewhere how a woman's value was measured in terms of her capacity to increase the number of children, especially male children, she could give to the family, to the patrilineage, and to the kindred community. ${ }^{71}$ If she could bear many healthy male children, she would be recognized as having fulfilled her main function that was to carry on her husband's line and to ensure the continuation of lineage. At any rate, an Albanian husband, usually seconded by his own group, treated his wife differently depending on whether she was merely a wife for him or he saw her as the mother of his male children.

A male was to give the house its name, protect the honor, lead the family group, and inherit the homestead. The man was therefore defined as the principal actor, being responsible, self-reflexive, and rational. He was the subject, she was object, and no matter how functionally important female activities might be. He was the defender of honor against humiliation, expected to protect his woman, as long as he valued her as a "resource," that is, as a prize and symbol of his honor or as a mother of his children. A female was worthy with reference to the interests of her male 
protector, her husband, her master, and lord. Her task was to give birth to his children and serve as a symbol and prize for his male honor. This was the traditionalist ideal of a proper woman.

In this way, women were left with their social status feature and their socially valued function to be founded exclusively on their capacities of procreation and motherhood. Fertility was the prime quality that enabled a woman to be considered by others, and to consider herself, as a person on her own full right. The process of her socialization was meant to satisfy a single desire: becoming a mother. The fate of an Albanian woman was bound up, in one way or another, with the history of her biological misfortune in the case she could be barren or bear children who were sickly or died at birth. She was often held in contempt and was regarded as an unfinished being, someone who was incomplete and totally deficient. Customary laws may even have explicitly stated that vajza pa u ba nanë s'asht e zoja e vedit, literally "a young woman who does not become a mother lacks ownership of herself," 72 in the sense of not being a person in her own right. A woman was regarded "unworthy" and of little account inasmuch as she could not give her husband children or otherwise enhance the honor of his family.

The stress on bearing children, especially male children, was aimed to reinforce the traditionalist prestige structures of Albanian patriarchal society, thereby inevitably based on men, with women considered only as material demonstrations of male power play. However, it is a crude misconstruction of reality to take patriarchally valued moral statements at face value and consider them for more than an expression of patriarchal ideology and propaganda. The "patriarchal" view of Albanian women is frequently taken for granted and has been often grossly overestimated. Albanian notions regarding gender identity must be seen as both enmeshed within and central to a far broader view of society that emphasized the precedence of patrilineal descent. It is thus a whole social order, and perhaps a cosmology as well, that must be appraised in any consideration of gender. Kinship systems and social structures are practices as well as ideologies, and both dogmas and practices impinge on women, gender relations, procreation beliefs, and socializing strategies. In this sense, the drive toward coherence in Albanian context is due to the traditionalist discourse of the patriarchal ideological concern with the silencing and totalizing effect symbolic practices are supposed to have in public life, especially with regard to women.

The urgent need for many children and large family cannot be so much a distinctive feature of a reified "Balkan Patriarchy," as Kaser ${ }^{73}$ and his associates would want us to believe. Rather, we may reasonably consider that ritual activity and collective representations of reproduction, which put systematic emphasis on women's childbearing function, must be a kind of cultural activism and policy as an effective instrument of patriarchal ideology and propaganda on behalf of the agnatic group. Eventually, the power play of such a male strategy seems to be not unlike the cultural activism launched by more modern and better organized social groups in other domains, including for that matter religious, nationalist, and communist pronatalist policies, which seem essentially to be instrumental political resources for ascertaining hierarchical relations among social groups and individuals, with women often used as a currency of exchange. Both cultural activisms and policies are total social phenomena insofar as they speak to ideologies and serve as statements of the "ethical" social system. ${ }^{74}$ Like policy making in more modern settings, cultural efforts in patrilineal groups to control reproduction enable the social system to redefine its boundaries and express its preferred moral orientations.

The politicization of reproduction issues is neither new nor surprising. In the broader context of reproductive relations, the patriarchal view of women's fertility is something that can threaten or reinvigorate not only the family but also the patrilineal group as well as the modern nation. In this sense, the analysis of traditional cultural activism in Albanian context leads me to consider that, such as more modern pronatalist policies and political discourses, it serves as a sort of "social Viagra,"75 aimed to fortify the political terrain of the patrilineal group like that of the nation-state struggling to achieve a durable and confident identity. Just as Viagra is designed to pump life into an impotent 
man, so the discursive incitement around the urgent need for many children does attempt to reinvigorate an "impotent" social system toward a large family structure. Furthermore, although the discursive strategies of cultural activism and policies primarily target women, the Viagra metaphor reminds us that the urgent need for many children and large family is not just a "women's problem" but also reminds us of the importance of virility. Because of the relationality of gender, it is a social phenomenon that intrinsically involves the construction of masculinity as well as sexuality.

The values that justified gender stratification in Albanian society cannot be understood as emanating from consensus or submission but from the conflict of opposing interests defined along gender lines. In addition, the historical circumstances responsible for the emergence, preservation, and reinforcement of this outmoded local social system do call attention to the fact that "patriarchy" was not merely a set of convenient ideas put into practice by dominant males. It is the external and historical conditions, including high levels of mortality, which defined optimal courses of action in the area of survival, while they related the resulting conditions of social existence to such ideal logical mechanisms that expressed the conflicts inherent in the established systems of gender roles and statuses.

The cultural pressure aimed at limiting Albanian women to their childbearing function, more than anything else allows us to account for the structural, historical, and political conditions in which social behavior take place. This is not, however, to offer a blanket condemnation of a given culture. Acknowledging the cultural dimensions of human acts and motives need not imply a simplistic understanding of "culture," which reduces all members of a community to social beings who "have a culture" and who are "culturally determined" in their individual experiences and their personal aspirations, nor that they are preprogrammed to react in the same manner.

\section{Conclusion}

The specific political instrumentality of cultural activism related to the urgent need for many children and deployed by the patriarchal ideals of agnatic community certainly appears unusual, and difficult to grasp, if one schematically uses traditional categories developed in current scholarship dealing with this question. In turn, an articulate analysis of the main available empirical evidence, linked to a careful examination of the historical contextualization in ideological perspective, is likely to produce a more sophisticated understanding of the myth of many children in Albanian context. While analyzing the cultural activism in which influential ideas in Albanian society have emerged, the aim of this article was to frame the argument in such a way as to take away from the close association of high fertility rates with a low age at marriage and present the urgent need for children as an ideological elaboration of patriarchy on behalf of the agnatic group, not unlike such modern statesponsored pronatalist policies of more infamous nationalist and communist ideologies.

In methodological terms, I tried to engage with an analysis of ideas rather than with a search for positive historical, ethnographic, or empirical proof. Such an analytical method that emerges from the specific content of both quantitative and ethnographic data is a complementary way of exploring the role of cultural models in group behavioral differences. Such research ideally produces knowledge that is both content rich and informed by the diversity of ways through which individuals think, feel, work, and play their way through life. Such techniques hold the potential to help explain how differences in thought and behavior over the life course are molded and maintained in different populations.

This approach might not be exhaustive and certainly a number of questions remain open. However, if this article has managed to provoke at the very least a nonstereotyped discussion throughout an interesting set of cogent reflections on Albanian cultural activism and its association with patriarchal ideology, it will hopefully constitute a starting point for further, deeper enquiries that can suggest alternative explanations. Ultimately, while the difficulty of simultaneously using 
distinct approaches is clearly realized, I believe the attempt to articulate them in relation to one another may lead to a fascinating intellectual problem. The conceptual aspects of this situation do not only show how to deal with an extant social structural problem but may also have important theoretical and methodological implications beyond that of the specific problems addressed in this article.

They suggest that it is important not to rely on surface observations of quantitative data and behavioral differences or ethnography alone. Rather, critical analysis of empirical evidence and intersections of ethnography with systematic and structured data collection can yield new insights in the space between idiographic and nomothetic understandings of culture, mind, and behavior. A new generation of ethnographically informed quantitative techniques altogether with a new way of approaching the available empirical evidence may reveal that behavioral differences are often supported by differences in the distribution, organization, and weighting or salience of idiosyncratic variation in cultural models and values.

\section{Declaration of Conflicting Interests}

The author(s) declared no conflicts of interest with respect to the authorship and/or publication of this article.

\section{Funding}

The author(s) received no financial support for the research and/or authorship of this article.

\section{Notes}

1. Faye Ginsburg and Rayna Rapp, eds., Conceiving the New World Order: The Global Politics of Reproduction. (Berkeley: University of California Press, 1995).

2. Michel Foucault, Naissance de la biopolitique: Cours au Collège de France, 1978-1979, ed. Michel Senellart, Hautes études (Paris: Gallimard/Seuil, 2004).

3. For instance, the Southern Albania Census recorded in the Ottoman tax register of 1431 or the record of matrimonial contracts from May 1, 1819 to December 12, 1843, in the Orthodox Codex of St. Cosmo Church, near Fier in Southwestern Albania. See Halil Inalcik, ed. Hicrî 835 tarihli Sûret-i Defter-i Sancak-i Arvanid [The 1431 Ottoman tax register of (Southern) Albania] (Ankara, 1954); Llambrini Mitrushi, "Kodiku i Manastirit të Shën Kozmait për kontratat e fejesave," Etnografia Shqiptare, no. 3 (1966): 177-246.

4. Franz Seiner, Ergebnisse der Volkszählung in Albanien in dem von den österreichisch-ungarischen Truppen 1916-1918 besetzten Gebiete, Linguistische Abteilung, 13 (Wien: Schriften der Balkan Kommission, 1922).

5. See the University of Graz ongoing Project "The 1918 Albanian Population Census: Data Entry and Basic Analyses" at http://www-gewi.kfunigraz.ac.at/suedost/seiner.

6. See the information on socioeconomic indicators available at the Albania Institute of Statistics (http:// www.instat.gov.al/).

7. See Leo Morris, Joan Herold, Silva Bino, Alban Ylli, and Danielle Jackson, eds. Albania Reproductive Health Survey, 2002 (Final Report), Tirana: Institute of Public Health, DRH/CDC \& USAID/UNFPA/UNICEF, 2005 (http://pdf.usaid.gov/pdf_docs/PNADG586.pdf).

8. The survey work was undertaken by the Living Standards unit of the Albania Institute of Statistics (INSTAT), with the technical assistance of the World Bank (See details and data at http://go.worldbank. org/IFS9WG7EO0). Data resulted from the 2008 LSMS are released in April 23, 2009.

9. See Albania Demographic and Health Survey, 2008-2009, Tirana: Institute of Statistics \& Institute of Public Health, 2010. 
10. A significant selection of these data are published in a single representative volume, where a careful attention is paid, whenever possible, to the exact conditions of field data reporting, and further details can be found on the area, local place and time, on the agents of transmission, on the ritual and ceremonial modes of practice, on the informants, including age, gender, and socioeconomic family status, on the conditions of ethnographic writing and technical recording, and so on. See Albert Doja, ed. Këngë të lindjes dhe ninulla, Trashëgimia Kulturore Shqiptare, Folklor IV, Lirika Popullore, 4 (Tirana: Akademia e Shkencave, 1990).

11. The research focused mainly on democracy and democratization processes involving human, cultural, and social factors in the area. See Albert Doja, "Démocratie et stabilité dans le Sud-Est Européen: facteurs humains, culturels et sociaux," Les Temps Modernes 56, no. 615-616 (2001): 147-166 (http://halshs. archives-ouvertes.fr/halshs-00406297/fr/); Albert Doja, "Conditions nécessaires à la stabilité et à la démocratisation dans le Sud-Est européen," in Intégration des 'minorités' et nouveaux espaces interculturels, ed. Aline Gohard-Radenkovic, Donatille Mujawamariya, and Soledad Perez, Transversales: Langues, Sociétés, Cultures et Apprentissages, vol. 6, 29-48 (Bern: Peter Lang, 2003).

12. Eugene A. Hammel, "A Theory of Culture for Demography," Population and Development Review 16, no. 3 (1990): 455-85 (http://www.jstor.org/stable/1972832); Robert A. Pollak and Susan Cotts Watkins, "Cultural and Economic Approaches to Fertility: Proper Marriage or Mesalliance?" Population and Development Review 19, no. 3 (1993): 467-96 (http://www.jstor.org/stable/2938463).

13. Hillard Kaplan, Kim Hill, Jane Lancaster, and A. Magdalena Hurtado, "A Theory of Human Life History Evolution: Diet, Intelligence, and Longevity," Evolutionary Anthropology: Issues, News, and Reviews 9, no. 4 (2000): 156-85.

14. David J. Harding, "Cultural Context, Sexual Behavior, and Romantic Relationships in Disadvantaged Neighborhoods," American Sociological Review 72, no. 3 (2007): 341-64 (http://www.jstor.org/stable/ 25472467).

15. Beatrice Whiting and John W. M. Whiting, Children of Six Cultures: A Psycho-cultural Analysis (Cambridge, MA: Harvard University Press, 1975).

16. Dorothy Holland and Naomi Quinn, eds. Cultural Models in Language and Thought (Cambridge: Cambridge University Press, 1987); Roy G. D’Andrade and Claudia Strauss, eds. Human Motives and Cultural Models, Publications of the Society for Psychological Anthropology, 1 (Cambridge: Cambridge University Press, 1992); Claudia Strauss and Naomi Quinn, A Cognitive Theory of Cultural Meaning, Publications of the Society for Psychological Anthropology, 9 (Cambridge: Cambridge University Press, 1997).

17. Clifford Geertz, The Interpretation of Cultures (New York: Basic Books, 1973).

18. A. Kimball Romney and Carmella C. Moore, "Toward a Theory of Culture as Shared Cognitive Structures," Ethos 26, no. 3 (1998): 314-337, doi:10.1525/eth.1998.26.3.314.

19. Sara Harkness and Charles M. Super, eds., Parents' Cultural Belief Systems: Their Origins, Expressions, and Consequences, Culture and Human Development (New York: Guilford Press, 1996).

20. Albert Doja, "L'enchantement socialisateur: la berceuse dans la tradition orale," in De la voix au texte: l'ethnologie contemporaine entre l'oral et l'écrit, ed. Nicole Belmont and Jean-François Gossiaux, Actes du $119 \mathrm{e}$ Congrès national des sociétés historiques et scientifiques, 85-108 (Paris: Éditions du CTHS, 1997 [http://halshs.archives-ouvertes.fr/halshs-00421805/fr/, http://eprints.ucl.ac.uk/18366/]); Albert Doja, “Le comportement symbolique autour de la prime enfance," L'Ethnographie: Revue de la Société d'Ethnographie de Paris 93, no. 1-2 (1997): 43-87; Albert Doja, "Développement corporel et transition sociale chez les Albanais," Journal of Mediterranean Studies 9, no. 2 (1999): 232-74 (http://eprints.ucl.ac.uk/19157/, http:// halshs.archives-ouvertes.fr/halshs-00467400/fr/); Albert Doja, Naitre et grandir chez les Albanais: la construction culturelle de la personne (Paris/Montreal: L'Harmattan, 2000 [http://halshs.archives-ouvertes.fr/ halshs-00406333/fr/]).

21. W. Penn Handwerker, "The First Demographic Transition: An Analysis of Subsistence Choices and Reproductive Consequences," American Anthropologist 85, no. 1 (1983): 5-27, doi:10.1525/ 
aa.1983.85.1.02a00010; David P. Kennedy, "Cognitive Models of Fertility Decline in Oaxaca City, Mexico," Population \& Environment 25, no. 3 (2004): 243-74, doi:10.1023/B:POEN.0000032323.39780.eb.

22. Jennifer Johnson-Hanks, "On the Limits of Life Stages in Ethnography: Toward a Theory of Vital Conjunctures," American Anthropologist 104, no. 3 (2002): 865-80, doi:10.1525/aa.2002.104.3.865.

23. Bradd Shore, Culture in Mind: Cognition, Culture, and the Problem of Meaning (New York: Oxford University Press, 1996); W. Penn Handwerker, "The Construct Validity of Cultures: Cultural Diversity, Culture Theory, and a Method for Ethnography," American Anthropologist 104, no. 1 (2002): 106-122, doi:10.1525/aa.2002.104.1.106.

24. George Lakoff and Mark Johnson, Metaphors we live by, 2nd ed. (Chicago: University of Chicago Press, 2003).

25. Albert Doja, "Évolution et folklorisation des traditions culturelles," East European Quarterly 32, no. 1 (1998): 95-126 (http://eprints.ucl.ac.uk/16551/, http://halshs.archives-ouvertes.fr/halshs-00406308/fr/).

26. Roland Barthes, "Le mythe aujourd'hui," in Oeuvres completes, 681-719 (Paris: Seuil, 1957; reprint, 1993).

27. Herman Bausinger, Volkskunde ou l'ethnologie allemande: de la recherche sur l'antiquité à l'analyse culturelle (Paris: Éditions de la Maison des sciences de l'homme, 1993).

28. Albert Doja, "Cultural Politics and Spiritual Making of Anthropologists," Reviews in Anthropology 33, no. 1 (2004): 73-94, doi:10.1080/713649341 (http://halshs.archives-ouvertes.fr/halshs-00406236/fr/).

29. See Karl Kaser, Siegfried Gruber, and Robert Pichler, eds., Historische Anthropologie im südostlichen Europa: eine Einführung (Wien: Böhlau, 2003).

30. John Hajnal, "European marriage patterns in perspective," in Population in History: Essays in Historical Demography, ed. D. V. Glass and D. E. C. Eversley, 101-143 (Chicago, IL: Aldine, 1965; reprint, 2008).

31. John Hajnal, "Two Kinds of Preindustrial Household Formation System," Population and Development Review 8, no. 3 (1982): 449-94 (http://www.jstor.org/stable/1972376).

32. Peter Laslett, "Family and household as work group and kin group: areas of traditional Europe compared," in Family forms in historic Europe, ed. Richard Wall, Jean Robin, and Peter Laslett, 513-563 (Cambridge: Cambridge University Press, 1983).

33. Karl Kaser, Familie und Verwandtschaft auf dem Balkan: Analyse einer untergehenden Kultur (Wien: Böhlau, 1995).

34. Theo Engelen and Arthur Wolf, eds., Marriage and the Family in Eurasia: Perspectives on the Hajnal Hypothesis, Life at the Extremes (Amsterdam: Aksant, 2005).

35. Karl Kaser, Hirten, Kämpfer, Stammeshelden: Ursprünge und Gegenwart des Balkanischen Patriarchats (Wien: Böhlau, 1992), 173-294.

36. Johann-Georg Hahn, Albanische Studien (Jena: Mauke, 1854), I.143, I.180.

37. Edith Durham, Some Tribal Origins, Laws and Customs of the Balkans (London: Allen \& Unwin, 1928; reprint, 1979), 192.

38. Carleton Coon, The Mountains of Giants: A Racial and Cultural Study of North Albanian Mountain Ghegs. Papers of Peabody Museum of American Archæology and Ethnology, 23 (Cambridge, MA: Harvard University Press, 1950), 27.

39. Kaser, Familie und Verwandtschaft auf dem Balkan: Analyse einer untergehenden Kultur, 153.

40. Bajram Mejdiaj, "Disa tipare të martesës para çlirimit,” Etnografia Shqiptare, no. 8 (1976): 33-108; Abaz Dojaka, Martesa në Shqipëri [Marriage in Albania] (Tirana: 8-Nentori, 1986).

41. Bette Denich, "Sex and power in the Balkans," in Woman, culture, and society, ed. Michelle Rosaldo and Louise Lamphere, 243-262 (Stanford, CA: Stanford University Press, 1974).

42. Albert Doja, "Le sexe de la naissance: masculin-féminin dans la société traditionnelle albanaise," Ethnologie Française 25, no. 4 (1995): 650-67 (http://halshs.archives-ouvertes.fr/halshs-00406292/fr/); Albert Doja, "Morphologie traditionnelle de la société albanaise," Social Anthropology: Journal of the European Association of Social Anthropologists 7, no. 1 (1999): 37-55, doi:10.1017/S0964028299000038 (http:// eprints.ucl.ac.uk/16544/, http://halshs.archives-ouvertes.fr/halshs-00406287/fr/); Doja, Naitre et grandir chez les Albanais: la construction culturelle de la personne; Albert Doja, "Rethinking the Couvade," 
Anthropological Quarterly 78, no. 4 (2005): 919-51, doi:10.1353/anq.2005.0053 (http://halshs. archives-ouvertes.fr/halshs-00406278/fr/); Albert Doja, "Instrumental Borders of Gender and Religious Conversions in the Balkans," Religion, State \& Society 36, no. 1 (2008): 550-63, doi:10.1080/ 09637490701809738 (http://halshs.archives-ouvertes.fr/halshs-00425476/fr/).

43. Albert Doja, "À propos de la diversité locale des traditions culturelles albanaises," Ricerca Folklorica: Contributi allo Studio della Cultura delle Classi Popolari 38, no. 1-2 (1998): 63-74, doi:10.2307/ 1479953 (http://halshs.archives-ouvertes.fr/halshs-00406313/fr/).

44. Gentiana Kera and Enriketa Pandelejmoni, "Marriage in Urban Albania (during the first half of the twentieth century)," The History of the Family 13, no. 2 (2008): 126-37, doi:10.1016/j.hisfam.2008.05.001, 132.

45. Coon, The Mountains of Giants: A Racial and Cultural Study of North Albanian Mountain Ghegs, 24.

46. Ermelinda Meksi and Pietro Iaquinta, “Aspects de l'évolution démographique en Albanie," Population (French Edition) 46, no. 3 (1991): 679-92 (http://www.jstor.org/stable/1533410), 685.

47. Kera and Pandelejmoni, "Marriage in Urban Albania (during the first half of the twentieth century).

48. Kera and Pandelejmoni, "Marriage in urban Albania (during the first half of the twentieth century)," 134.

49. Maria Todorova, Balkan Family Structure and the European Pattern: Demographic Developments in Ottoman Bulgaria (Lanham, MD: University Press of America, 1993), 131.

50. E.g., Todorova, Balkan Family Structure and the European Pattern: Demographic Developments in Ottoman Bulgaria.

51. Peter Laslett, ed. Household and Family in Past Time (Cambridge: Cambridge University Press, 1972).

52. Abaz Dojaka, "Familja shqiptare dhe zhvillimi i saj historik," Kultura Popullore 11, no. 2 (1990): 113-27.

53. E.g., Berit Backer, Behind Stone Walls: Changing Household Organization Among the Albanians of Kosova, ed. Antonia Young and Robert Elsie (Peja: Dukagjini Books, 2003 [http://www.elsie.de/en/books/b31. html]).

54. Jack Goody, ed. The Developmental Cycle in Domestic Groups, Cambridge Papers in Social Anthropology, 1 (Cambridge: Cambridge University Press, 1958); Jack Goody, Domestic groups (Reading, MA: AddisonWesley, 1972).

55. Siegfried Gruber and Robert Pichler, "Household Structures in Albania in the Early 20th Century," The History of the Family 7, no. 3 (2002): 351-74, doi:10.1016/S1081-602X(02)00106-9, 371.

56. Beryl Nicholson, "Women who Shared a Husband: Polygyny in Southern Albania in the Early 20th Century," The History of the Family 11, no. 1 (2006): 45-57, doi:10.1016/j.hisfam.2005.07.001, 52.

57. Siegfried Gruber, "Household Structures in Urban Albania in 1918," The History of the Family 13, no. 2 (2008): 138-151, doi:10.1016/j.hisfam.2008.05.002, 149.

58. Gruber, "Household Structures in Urban Albania in 1918," 144.

59. See http://www-gewi.kfunigraz.ac.at/suedost/seiner

60. Tim Dyson and Mike Murphy, "The Onset of Fertility Transition," Population and Development Review 11, no. 3 (1985): 399-440 (http://www.jstor.org/stable/1973246).

61. Meksi and Iaquinta, “Aspects de l'évolution démographique en Albanie," 684-85.

62. Arjan Gjonça, Arnstein Aassve, and Letizia Mencarini, “Albania: Trends and Patterns, Proximate Determinants and Policies of Fertility Change," Demographic Research 19, no. 11 (2008): 261-92 (http://www. demographic-research.org/Volumes/Vol19/11/).

63. John Bongaarts, "The Role of Family Planning Programmes in Contemporary Fertility Transitions," in The continuing demographic transition, ed. Gavin W. Jones, 422-43 (Oxford/New York: Clarendon/Oxford University Press, 1997).

64. Monica Das Gupta, "Life Course Perspectives on Women's Autonomy and Health Outcomes," American Anthropologist 97, no. 3 (1995): 481-91 (http://www.jstor.org/stable/683268).

65. Lila Abu-Lughod, Veiled Sentiments: Honor and Poetry in a Bedouin Society (Berkeley: University of California Press, 1986).

66. Maurice Bloch, "From Cognition to Ideology," in Power and Knowledge: Anthropological and Sociological Approaches, ed. Richard Fardon, 21-48 (Edinburgh: Scottish Academic Press, 1985). 
67. Albert Doja, "Dreaming of Fecundity in Rural Society," Rural History: Economy, Society, Culture 16, no. 2 (2005): 209-33, doi:10.1017/S0956793305001482 (http://eprints.ucl.ac.uk/16542/, http://halshs. archives-ouvertes.fr/halshs-00406280/fr/).

68. Doja, "Rethinking the Couvade."

69. Albert Doja, "Sworn Virgins, Incoming Husbands, and Shared Wives: Performing the Gendered Social Order," (forthcoming).

70. Doja, ed. Këngë të lindjes dhe ninulla, 133-35.

71. Doja, Nattre et grandir chez les Albanais: la construction culturelle de la personne.

72. Shtjefen Gjeçov, Kanuni i Lekë Dukagjinit, ed. K. Nova, Expanded ed., Trashëgimia Kulturore Shqiptare, e Drejta Zakonore, 1 (Tirana: Akademia e Shkencave, 1989), 64.

73. Kaser, Hirten, Kämpfer, Stammeshelden: Ursprünge und Gegenwart des Balkanischen Patriarchats.

74. cf. Susan Wright and Chris Shore, eds., Anthropology of policy: critical perspectives on governance and power (London: Routledge, 1997).

75. cf. Elizabeth Krause and Milena Marchesi, "Fertility Politics as "Social Viagra:" Reproducing Boundaries, Social Cohesion, and Modernity in Italy," American Anthropologist 109, no. 2 (2007): 350-62, doi:10.1525/aa.2007.109.2.350.

\section{Bio}

Albert Doja is an Honorary Research Fellow at the Department of Anthropology, University College London, and Professor of Sociology \& Anthropology at the European University of Tirana. He is qualified University Professor in France and elected in 2008 a full ordinary member of the Albanian Academy of Sciences, holder of the first Chair of Social Anthropology. He was awarded with distinction a PhD in Social Anthropology in 1993 from the École des Hautes Études en Sciences Sociales in Paris and a Professorial accreditation (Habilitation à Diriger des Recherches) in sociology and anthropology in 2004 from the University of Paris-5, Sorbonne. He has been on secondment to the United Nations Development Programme under the Brain Gain Initiative as the Deputy Rector of the University of Durres in Albania and has held several academic positions in France, Britain, Ireland, and Albania, lectured on social anthropology and conducted extensive fieldwork research in many other countries. He is on the editorial board of several international academic journals and published a number of books and about seventy original articles in international peer-reviewed journals. His special interests include technologies of the body, personhood, gender construction, kinship, and reproduction activism; anthropology of symbolism and communication; intercultural communication, interethnic relations, and international migrations; ethnicity and nationalism; politics of identity and religion; power and ideology; cultural heritage and social transformations; anthropology of history; anthropological theory, structuralism, poststructuralism and neostructuralism. 